\title{
The Formularization of the East Simulacrum in the Poetic Consonance of Walter De La Mare
}

\author{
Hazhar Ramadhan Ahmed \\ Islamic Higher School, Directorate of Rania Education, Ministry of Education, Rania, Kurdistan \\ Regional, Iraq. \\ Email: Hejar.remazan@gmail.com
}

\begin{abstract}
:
The desideratum of this paper is to view the formularization of the East simulacrum in the poetic consonance of Walter De La Mare. De La Mare was always been known as a writer of fantasy, imagination world and supernatural fiction in English literature. It is proposed here that he is, in fact concerned with the exploration of the conscious and unconscious selves.

His inspection is more philosophical than psychological in that he makes no use of Freud formulas. He follows rather the intuitive path of Jung but uses the media of fiction. Display and formulation the simulacrum theme in two sonnets of De La Mare "Arabia \& Listener " characterize the imagination world of the East.

East fantasy for De La Mare is a pure and marvelous creation which seemed he merged the fantasy cosmos of the East, even supposing Walter De La Mare wants to involve and remain in the nature of the East not in the West creation by virtue of him in distinction to the West. According to his verses of Walter De La Mare "Arabia \&Listeners " there is no ambiguity that nature in the East more applicable for lives than nature in the West.
\end{abstract}

Key words: formularization, East simulacrum \& poetic consonance. 


\title{
1. Introduction
}

\author{
Far are the shades of Arabia \\ Where the princes ride at noon, \\ Mid the verdurous vales and thickets, \\ Under the ghost of the moon, \\ And so dark is that vaulted purple, \\ Flowers, in the forest ride, \\ And toss into blossom against the phantom stars.
}

Walter de la Mare (1873-1953). In two poems "Arabia \& Listeners " characterize and particularize the East simulacrum. Walter De La Mare confers that the East is the creation of a marvelous nature. According to this paper researcher fling to scrutinize the two poems of "Arabia \& Listeners " furthermore display and conversing about the main themes of the poems towards the inspiration world of the East. In both American and British Literature some poets divulged the illustration of the East. Walter John De La Mare is one of the splendid poets that deliberated the imagination of the East.

The "listeners" is written in 36 lines with remarkable rhyme scheme. It's written in a very clean style. It can be discern as a story to kids. It can also be explained by an adult. It's undeniably a story poem that can be implied in diverse ways. "The Listeners" communicate the story of adventurer who knocks at a door of a house but nobody answers. No one is even ready to listen to him. The poem is written in a supernatural aspect. It depicts the incidents that happen in the real world and the world of phantoms.

The "Arabia" which is consist 24 lines, in his poetry fantasy and actuality concoction as in a simulacrum. The allure De La Mare sees in this world is grabbed and transfigured by his vision of a faraway world of Romance which is at once real and unreal. He has been characterized as the last Romantic poet in English Literature."Arabia" far-off ground from the western moiety, yet in the middle of the world, "Arabia" is a ground of sandy deserts. 


\section{Methodology}

Walter De La Mare terminated the imagination of the East in two poems which are "Arabia and Listeners ". This paper is consider to interrogate the supposition of the East in both poems of De La Mare, in addition to that confabulate and finding that motivated the poet to address the East will be another target of the paper. The paper adopted descriptive analytic method for analyzing two poems of Walter De La Mare "Arabia \& Listeners". Comments and different ideas are given as well. Then the review of Literature which deal with the De La mare biography and the theory of East in his poetic variety ,and analyzing the two sonnets of " Arabia \& listeners " which are formulation the East simulacrum and the creation of the West. Lastly, the conclusion and Recommendations are stated to remain the reader of the formularization of the East simulacrum in the poetic consonance of Walter De La mare.

\section{Background and literature Review}

\section{Walter de la Mare (1873-1953) - pen name Walter Ramal}

British lyricist and novelist loosely concerned with the literary tradition of Wordsworth and Coleridge. De la Mare's reputation as a poet was established by the volume The Listeners and Other Poems (1912). Vita Sackville-West once called him a "poet of dusk". De la Mare wrote for both children and adults. His best-known novel is Memoirs of a Midget (1921) that characterized sympathetically the world of the minute Miss M. or Miss Thomasine, who is regarded as a freak. The book won the James Tait Black Memorial Prize in 1922.

\section{Look thy last on all things lovely, Every hour - let no night \\ Seal thy sense in deathly slumber \\ Till to delight, \\ Thou hast paid thy utmost blessing.}

Walter de la Mare was born at Charlton, Kent, in the south of England, of well-to-do parents. His father, James Edward De La Mare (as the name was originally spelled), was an official of the Bank of England. His mother, Lucy Sophia (Browning), was related to the poet Robert Browning. He was educated in London at St. Paul's Cathedral Choir School, which he left aged 16. From 1890 to 1908 he worked in London in the accounting department of the Anglo-American Oil Company. His career as a writer started in about 1895 and he continued to publish to the end of his life. His first published story, 'Kismet' (1895), appeared in the Sketch under the pseudonym Walter Ramal.

In 1908 de la Mare was awarded a yearly government pension of $£ 100$, and he devoted himself entirely to writing. He retired to Taplow in Buckinghamshire, where he lived calmly with his wife, Constance Elfrida Ingpen (died 1943), and four children. De la Mare's oldest son Richard became Chairman of Faber \& Faber, and published several of his father's books. The slaughter of WWI left weariness in his work for a long period. "Heavenly Archer, bend thy bow; / now the flame of life burns low, / Youth is gone; I, too, would go" he wrote in a poem (in 'Dust to Dust', Motley, 1918). From 1940 until his death, he had a flat at South End House, Montpelier Row.

De la Mare received the CH in 1948 and the OM in 1953. He died in Twickenham, near London, on June 22, 1958. De la Mare is buried in St Paul's Cathedral.His first works de la Mare wrote for periodicals, for The Sketch amongst others, and published in 1902 a collection of poetry, Songs of Childhood, under the name Walter Ramal. It attracted little notice. Subsequently de la Mare published many volumes of poetry for both adults and children. In 1904 there appeared under his own name the prose romance Henry Brocken, in which the young hero sets out an allegorical 
journey. Brocken encounters fictional characters and writers from the past, but he is eventually cast back from the book lands to mortality. A similar theme about the relationship between real and fictional was taken up in The Return (1910), an eerie story of spirit possession. Arthur Lawford suspects that an eighteenth-century pirate, Nicholas Sabathier, is seizing control of his personality. "'Here lay bones of one, Nicholas Sabathier,' he began murmuring again - 'merely bones, mind you; brains and heart are quite another story. And it's pretty certain the fellow had some kind of brains. Besides, poor devil, he killed himself. That seems to hint at brains".

De la Mare's first successful book was The Listeners; the title poem is one of his most anthologized pieces. In the work supernatural presence haunts the solitary Traveller, the typical speaker of his poems: "Is there anybody there? said the Traveller, Knocking on the moonlit door; And his horse in the silence champed the grasses Of the forest's ferny floor.

But no one descended to the Traveller; No head from the leaf-fringed sill Leaned over and looked into his grey eyes, where he stood perplexed and still. "Mare often described the English sea and coast, the secret and hidden world of nature. His favorite themes, childhood, death, dreams, commonplace objects and events, de la Mare examined with a touch of mystery and often with an undercurrent of melancholy. His novels have been reprinted many times in horror collections because of their sense of wonder, and also hidden malevolence. However, de la Mare did not have the morbid atmosphere of Poe, but his dreamlike visions had many similarities to Blake.

The poem of "Arabia " is another interest able peace work of him that he described the imagination of the East.in these two poems "Arabia \&Listeners" De La Mare distinguished the nature in the East and West. During de la Mare's lifetime, no full-length feature films were produced from his writings. The short story 'What Dreams May Come' (1936) was adapted for the TV series Tales of Tomorrow in 1953. 'Seaton's Aunt', a tale of vampirism written about 1909, was filmed in 1983 in the Granada Television series Shades of Darkness. Though not based on his work but on a play by R.A. Dick (Josephine Leslie, 1898-1979), The Ghost and Mrs. Muir (1947) contains many of the fantasy elements typical for a de la Mare story, such as the bondage between the material world and the spirit world.

\section{Three jolly gentlemen, \\ In coats of red, Rode their horses Up to bed.}

Among de la Mare's books of children verse and stories is Peacock Pie: A Book of Rhymes (1913) and Broomsticks and Other Tales (1925). One of de la Mare's most successful books for children was The Three Mullah Mulgars (1910), which told a story of three royal monkeys on a long journey. Later this animal fantasy was retitled The Three Royal Monkeys.

Come Hither (1923), which contains over 800 pages and covers approximately 600 years of literature in English, is a widely admired anthology for children. W.H. Auden said of it, "I remember very well the appearance, when I was a schoolboy, of Come Hither, a collection which, more than any book I have read before or since, taught me what poetry is" (The New Republic, Dec. 27, 1939).

Instead of an introduction, this anthology begins with a piece of autobiographical fiction, 'The Story of This Book'. The poems are gathered in sixteen separate sections; the titles have their own inner logic: "Morning and May", "Feasts: Fairs: Beggars: Gypsies", "summer: Greenwood: Solitude", "Dance, Music and Bells", and so on. The final section, "About and Roundabout" consists of 300 pages of notes on the poems.

De la Mare wrote about 100 short stories. The major collections include The Riddle and Other Stories (1923), On the Edge (1930), and A Beginning and Other Stories (1955). His early pieces were posthumously assembled as Eight Tales (1971). From the mid-1930s de la Mare wrote no more short stories, but focused on poetry. Never feeling any need to experiment, he used the old forms, the sonnet, and the quatrain. Graham Greene has argued that de la Mare was more interesting as a prose writer than a poet. Dylan Thomas was also an admirer of his fiction. Essays and critical work include studies of R. Brooke (1919) and Lewis Carroll-L.C. Dodgson (1932), and an edition of C. Rossetti in 1930. De la Mare was one of the legatees of his fellow poet Rupert Brooke. 


\section{Analysis and Discussion}

\subsection{The formularization of the East simulacrum in the poem of "Arabia "}

Walter De La Mare considered as one of the major poets who had concerned with an ideal world. Accordingly, the world that De La Mare had described in his poem "Arabia" is a world of perfection which lies somewhere outside the world of reality. This poem entirely interestingly because the poet described an ideal world which is ornamented by joy and beauty as if De La Mare formularizing of the east simulacrum as the source of beauty, Moreover this imaginative world is given in the title of "Arabia" in this poem the writer describes and uses many metaphors to show the real face of the East. In other words it may be argued that the state of a reader moves from reality to the imaginative world of poet, as she or he reads this poem because the poet depicted East in Arabia as the Land of fairs, beautiful roses, kings for the poet everything in the East is strange as if the world that exists in the East is unique and different from the West.

Hence, De La Mare can be placed as an escapist who writes about dreams and fancies because they cannot face the sorrows of real life. But, De La Mare says that every imaginative poem is like the experience of dreaming since, he dreams about east and Arabs as an ideal world that just exist in Arabia not in West. There is no doubt that the imaginative world is full of mysteries and fancies and this is one of the distinguished elements of De La Mare.

This uniqueness is created by joining the two worlds into one the real and imaginative one, which can be seen as the alternative world. According to John Middleton Murray who stated that "De La Mare is a poet of the great theme who is distinguished chiefly by his faculty of pressing invention and fancy to the service of his needs". In this sense, de La Mare creates an atmosphere in which it beaks the boundary between the two different worlds.

Concerning the first stanza, the poet describes Arabia as a beautiful place where the princes are sitting inside an attractive green forest. further the poet says there are princes while time is noon, stars do not appear in noon, therefore; he used his metaphor as if a ghost covered the moon and world is dark as if the poet wants to say that east has different features and even its nature is entirely different from other parts of the world. Besides, the writer said there are flowers in the forest where as in Arabia only, he argued that flowers of east are more beautiful than west as these flowers do represent nature in east.

One may ask why Walter De La Mare is anxious about East not west, and why in Arabia he creates a perfect world which is an imaginative one it may be because, the writer is far from Arabia hence, he described the place as an imaginative world. The world that Walter De La Mare dreams about it although the poet did not see Arabia, but in his imagination he could create the beautiful world that everything in it is unusual such as he said " the flowers, in the forest ride " he depicted the flowers in the forest which seem to grow quickly.

\section{Far are the shades of Arabia \\ Where the princes ride at noon, \\ Mid the verdurous vales and thickets, \\ Under the ghost of the moon, \\ And so dark is that vaulted purple, \\ Flowers, in the forest ride,}

And toss into blossom against the phantom stars.

The poet is attracted by those flowers because according to the poet flowers in the East are more beautiful than those in England because flowers in the East are natural not artificial that is why their beauty attracted the poet.in many cases, the poet compare the real things that exist in England to those that exist in the East. And also the stars in Arabia are imaginary stars which are "pale" and " phantom", since they can be seen in the noon. That is why the writer attracted by nature elements in Arabia ,because even those stars are not like the stars in England it is clear from the first couplet that De La Mare has his unique love for East, East is the world that poet would like and prefer to live in . On the other side it may be from the point that industrialization damaged the beauty of England but in East improvement was slow not like in west, thus the sense of nature in east disrupted Walter's mind. 
Stating that De La Mare had mixed both "reality" and "imaginary" world into one single world. Besides, this notion of the poet can be found in every single line and stanza by the poet. Thus, in the second stanza the poet goes on in describing the music of Arabia, which is sweet, he again refers to reality by saying "out of dreams" that means in reality when in dawn he sees the foggy and cloudy wealth this means the real situation.

\section{Sweet is the music of Arabia, In my heart, when out of dreams, I still in the thin clear mirk of dawn}

Furthermore, Walter continuous in discussing a woman in east who is likes a fair, this woman that sits beside the bank of the river and plays a lute; the poet is in chanted by this music because he never had heard this tone. He is attracted by this music because it's a mixture of saddens and happiness, sorrow and delight. He mentioned Lute which is musical instrument in East the tone is strange the poet created a special notion and his thoughts are busy with East if he is a dream poet. Furthermore, since he had never such kind of music which moves poet's emotions.

In addition to that description of the musicians are considered to be the people of Arabia as they have dark and dimskin that are playing in the silence of night near the bank. Eventfully, it could be estimated that this line is also refereeing to reality which depicts people in Arabia, but in the beginning of this stanza the world and the lady Arabia both are imaginary dream of the poet.

\section{Descry her gliding streams, Hear her strange lutes on the green banks, Ring loud with the grief, and delight, Of the dim-skinned, dark-haired Musicians, In the brooding silence of night}

Interestingly, in the third stanza the poet completely talks about the music of the second stanza and goes back to the first stanza. Moreover, as he said I have never seen such a beautiful lady like Arabia that is the reason he acknowledged that all beautiful things in this world are shadows of Arabia. In the first two lines he again concentrated on the beauty of Arabia as if the never had seen anything beautiful link Arabia when he imagines and dreams he remembers the beauty of Arabia, in this case this line reveals the human psychology because when someone sees something moving and attractive then remembers it. Lastly, the poet goes back to describe English people, these lines are real as he stated the people's eyes are looking at him because he was haunted by lady Arabia as if Arabia is a witch who bewitched the poet. Obviously, English people do not understand the poet because they cannot feel the beauty of East even in their dreams. Over all Walter De La Mare continually described East as place that exist no where.

\section{They haunt me her lutes and her forest; \\ No beauty on earth I see, But shadowed with that dream recalls, Her loveliness to me: Still eyes look coldly upon me, Clod voices whisper and say,}

Besides, people think that the poet is completely crazy and he sees everything coldly and even their voices are cold, as he heard the sweet voice of Arabia and her lute before, so he can not feel their voice, therefore; he is crazy as lady Arabia is not more available only she exists in his imaginations. Here in the last two lines everybody is entirely conceived that Walter became an insane man because of his desire for Arabia:

He is crazed with the spell of far Arabia,

They have stolen his wits way 


\title{
4.2 The formularization of the East simulacrum in the poem of "Listeners "
}

In "the Listeners" De La Mare describes a traveler who has come to knock on a moonlit door in an eerie, unknown place. He has come to keep an unnamed promise, and knocks on the door harder and harder, but gets no response. Unknowns to him, a "host of phantom listeners" (line 13) are inside but unresponsive to his calls. The traveler finally leaves, but the listeners remain. In this poem as well the poet graves metaphors that depict east and eastern people. In addition to that the listeners cloud is taken into account as eastern people because they live in a place far from England. Besides, the theme of the poem is the place of man in universe which is far greater than real world, and which he can neither connect with nor understand it. It focuses on man's isolation and disharmony with the natural world.

Accordingly, one important thing should be mentioned here, De La Mare's pomes are pervaded by feelings of mystery and wonder, also brooded on ultimate issues, the nature of time, of identity of dreams of death and whatever he thought about dissolved into uncertainty.Nature, as represented by the horse placidly munching on the grass and the bird frightened by the man's disturbing clamor, is normally serene- it is only man who is anxious because of his separateness. The traveler tries to overcome his loneliness and establish meaning by fruitless seeking, (knocking) and responsible living (keeping prom), but the natural world remains unyielding in keeping its distance, and the traveler continuous on alone. In this regard the eastern people who might be listeners who prefer to be silent to keep away from the traveler.

As far as they are living with nature and nature is an immortal friend for them. This idea is best viewed on Oliver Goldsmith's poem "The Deserted Village ."A sense of strangeness a reader feels as walking into the world of De La Mare's poetry. "I would be better to state very much the same kind of strangeness "the traveler" feels in the "Listeners" as in the poem the traveler smites upon the door, but no one answers".

\author{
Is there anybody there? Said the Traveler, \\ Knowing on the moonlit door, \\ And his horse in the silence champed \\ The grasses of the forest's ferny floor; \\ And a bird flew up out of the turret; \\ Above the Traveler's head \\ And he smote upon the door again a second time; \\ Is there anybody there?' He said, \\ But no one descended to the Traveler; \\ Leaned over and looked into his grey eyes, \\ When he stood perplexed and still
}

The title "The listeners" is apt as the listeners are the phantoms or the ghost. This poem divides the two different worlds, the world of the living (the traveler) and the world of the dead (the phantoms). The poem leaves behind many unanswered questions as whether the traveler is aware of that place; if he is then why he does not know that nobody is living there so on. As there was no one living there for long so the nature (bird) was not used to the noise made by the traveler so by the knocking the bird flew away from the nest. Then the traveler stuck (smote) the door for second time, but nobody came down towards the door (this line indicates that he might know that house as he says that nobody descended: he knew that there were stairs). The trees were growing wildly and not been checked so they were outlining or covering the still like a fringe (hair cut) covers the forehead, here from the description it is obvious that the place where the listeners belong to is east not west. Curiously, "The listeners" is one of his most anthologized pieces in which the work supernatural haunts the solitary traveler".

Host of phantom listeners,

That dwelt in the lone house then,

Stood listening in the quite of the moonlight,

To that voice from the world of men. 
so nobody bents or prepped out from there to look for who has come but there was no one but only phantoms who were standing on the stairs and the faint moonlight is falling on them like a spotlight. The traveler doesn't know that there were phantoms but he cloud feel that someone is there listening to his words (cry) the trees seem as if touching the sky.

Even though, the traveler again smote at the door and looked at the house and said that he has kept his promise (this tells that he knows someone in the house and once had promised to come back) than he climbed back to his horse and the phantoms can hear the traveler climbing on the horse back stepping the stirrup and the sound of the horse's hooves when stake on the stones can be headed. In this stanza the traveler is disappointed because the listeners do not answer him. As if listeners intentionally did not answer, the poet describes east as if it's a land of fairs, trees, moonlight and beautiful natural elements that Man could not disrupt, Obviously the listeners are somewhere else but in the world of men "on earth, since there is moon" this means far in East not West.

\title{
Stood thronging the faint moon \\ Beams on the dark stair, \\ That goes down to the empty hall, \\ Hearkening in an air stirred and taken \\ By the lonely Traveler's call, And he felt in his heart their strangers.
}

"The mystery is heightened but the poet's is of a few choices of words to create eerie supernatural atmosphere effect" . As in the lines above, the true beauty of the poem lies on some words "moonbeams, dark, empty, air stirred and shaken."

Also, the voice that comes from the lute in Arabia and the voice in the "Listeners" seem to be the same, as if De La Mare wanted to explain that the voices are similar in east because moon ins not covered by anything in east as far as in west the industrialization destroyed the beauty of nature.

However, "the voices may be mysterious for some readers but the natural voices are attractive". The listeners find out that the knock and the call both were made by a human being that is the main reason they did not answer. Although, the traveler felt in heart that listener were there but they did not want to answer.

Overall, Walter De La Mare had his unique style in describing East in his poems as if he loves east more than west. On the other hand, the poem is written on an open-ended style that makes every reader to have his/her own point of view. In this stanza he describes the traveler as a lonely person who is derived from his friends because he is from real world. The listeners seem to from imaginary world. "Fast because they are silent and patient, this is clear from the beginning because they even hear. But do not want to answer the traveler ".

\author{
Their stillness answering his cry, \\ While his horse moved, cropping the dark turf, \\ Neath the starred and leafy sky; \\ For he suddenly smote on the door, even \\ Louder, and lifted his head \\ Tell them I came, and no one answered, \\ That I kept my word, ' he said. \\ Never the least stir made the listeners, \\ Though every word he spoke
}


Moreover, in these lines the traveler repeats and said that I kept my word and I come, this means the traveler, kept his vow to the listeners, but they do not want to answer. The traveler has come to fulfill a duty. He had left something and promised to come back to it. It seems that a great time has passed. Whatever he left behind, he could now not summon. The sleeping group could not be stirred. He had communication with the listeners in the past -when the promise was made. "The listeners are now sleeping and won't wake ."

\section{Feel echoing through the shadowiness of the still house \\ From the one man left awake: Ay, they heard his foot upon the stirrup, And the sound of iron on stone, And how the silence surged softly backward}

When the plunging hoofs were gone at the end the traveler over and over retells that he came but so no answer, although he knows they are there but there is no answer. For example "the sound of iron on stone", when De La Mare used Iron and Stone as if the travelers heart is made of iron that is why he is late to the listeners and now listeners are phantoms. Perhaps the line "the one man left awake" shows that the listener were once people but have left themselves as if they are happy in their silent world.

Accordingly, a question asked by countless people who follow and love English literature is what had actually happened to the listeners in Walter de la Mare's poem by the same name? There has been a huge debate on this, besides, it is a debatable matter that is why there are different ideas about this poem, to some extent it cloud be mentioned that the house was a peaceful place where the traveler wanted to stay. Some readers think that traveler is from real world whereas listeners are from the imaginative one. On the other hand some readers have totally opposite ideas.

The traveler seems to be form west the real world that bored he and want find a peaceful place which is east. Most probably traveler is from the real world the industrialized world that disturbed nature in west hence, the traveler anxious to run away and fly to east to stay with the listeners that is many readers think that traveler is ghost. In this sense the traveler was a romantic person who loved nature but the listeners did not want his existence with them. Paul Drench stated "the topic of place and voice" invites anyone concerned with the Middle East and particularly in Arabia to go in search of shape and figures there.

If a comparison be made upon the themes and metaphors that been used in "Arabia" and "listeners" there is silence in the house like the stillness in Arabia, one may say the eastern people are mostly Muslims that is why De La Mare intentionally used dead, ghost, for explaining that the dead hear us but we do not, Islamic beliefs that there is always a spiritual communication between these two worlds of the dead and living.

De la Mare is confirming such a communication though some people may want be unaware like the listeners. The overwhelming sense of shattered stillness that rolls back like a wave once the "Traveler leaves, the sense of an ancient house with memories in the middle of a dark, ancient forest, The depiction of the place in the poem really takes you to the imagination world the same thing does exist in "Arabia". Another idea is that the poet wants to say the soul and life are interconnected and no one can change this because God guides us."

It is disputable to acknowledge that the poem takes place in a peaceful, overgrown forest with a seemingly dilapidated house/castle that we assume was once home to a family or group of people but is now being overtaken by the forest (leaf-fringed sills, the bird in the turret). De La Mare used the house and the forest as a symbol for the forces of nature in the world most probably nature in the East. The traveler is of "the world of men", therefore I see him as a representative of mankind. The poem represents the constant miscommunication and inability to coexist between man and nature. The traveler lives in a world that will live on long after he is gone, a world that does not share his impatience not his struggle to be understood.

Nature views man as a disturber of the peace, a member of the world that forces his desires and will upon all things around him no matter what damage he causes. Instead of answering his knocking demands, the listener just wait for 
him to leave so that the peaceful silence of the forest can return. " As the man made iron horseshoes clip clop on the naturally stony path ,man fades away and allows the forest to return to it is desire sublimity " The main aim of the poet is that nature is durable especially in the East because the eastern people love nature more than west as they are from rural area.

The first twelve lines create the quietness and darkness. It must be the dark forest, where only the moonlight can show the way of the traveler. The atmosphere is so quite that he can only hear his horse and the wings of the bird. Walter De La Mare created the same world in "Listener" \& "Arabia" for instance Lady Arabia plays Lute in this way she communicate with nature in the East, also the traveler is alone no one answer him.

The mysterious atmosphere is little by little up in the lines above and then, the poet reveals what is the fact listening to the traveler.no doubt at all that readers have different interpretation which convey different meanings.to begin with, Walter De La Mare had continued using similar themes, when a reader deal with the " The Listeners " he can explain that De La Mare amalgamated two worlds like in "Arabia" the world that the traveler belongs to is real world whereas the Listeners belong to unreal world, the world of imagination.

Besides, the listeners are symbolized as phantoms the world of the dead while the traveler relates to the world of the living. It should be stated that De La Mare has strange uses of the words to present the real nature, in this way he argued that nature in this place is beautiful because it's far from human beings, as if in the poem when the traveler comes and his horse munching the grasses because the horse undisturbed, but while the traveler came across the house the bird flew away from the nest.

The traveler is not aware that there is no body in this house but he still knows although no one answers, because listeners do not want to answer, however the traveler the traveler knows that there nature is save no one bother the natural world, trees, grasses everything is quite there as De La Mare said only "phantoms and faint moonlight" even though the traveler knew no one was there but he felt that phantoms were listening to him, the traveler could feel that someone is there. 


\section{Conclusion and Recommendations:}

Walter De La Mare in his poems "Arabia \& Listener " had depicted and formularized the simulacrum of the East, According to De La Mare the world of the East is imaginative and perfectible world. And De La Mare wants to stay in this world which is East, that is why he illustrated East in an extravagant path to captivate the mind of the reader. Additionally, creation of the East far from industrialism and nature is protected in East not Like the creation of the West furthermore Walter De La Mare tried to make a poetic consonance distinguish betwixt the nature of the East and West.

\subsection{Findings:}

1) De la Mare formularized the East simulacrum through of his poems "Arabia \& Listener" as impeccable creation.

2) The poet appetites to tell the society that nature is a part in our lives, thence people have to protect it from any harm.

3) Human beings and nature love each other but De La Mare stated this is formulated in the creation of the East not in the creation of the West, because De La Mare thought that new civilization in the west defeated the nature.

4) Population in the " Arabia \& Listener " are silent as if they lute their time " Carpi dam theme " they want to seize the time.

5) Lastly the poet characterized the simulacrum of the East in both poems clearly, because even De La Mare would like to stay with the phantom listener not with the traveler and England population and creation. 


\section{Bibliography:}

Bate, W. J. \& David. P (1906) British and American Poets: Chaucer to the Present. New York: Brace Jovanovich.

Chandra, S. (2009). What happened to the listeners in Walter De La Mare's poem: available online at: https://fitnessgear-equipment.knoji.com/what-happened-to-the-listeners-in-walter-de-la-mares-poem, September 22, Accessed on (November, 20, 2019).

Driesch, P. (1988). Segmentation: It's Roots in Arabia and Its Flowering Elsewhere." Cultural Anthropology, Vole, 3 (1): 50-67.

Davison, E. (1926). Walter de la Mare, the English Journal, Vol.15. No.2, available at: http://www.jstor.org/pss/802571, (Accessed on December 10, 2019).

Jake, W. (2006). The Listeners in De La Mare's World, available at:

http://www.guardia.co.uk/books/2006/jun/10/booksforchildrenandteenagersfeture, Accessed on (November 28, 2019).

John, M. M. (1950). The poetry of Walter de la Mare in John Clare and other stories: London, Peter Neville.

Leonard, C. (1954). Hand list of the writings in book from (1902-1953) of Walter de la Mare, Studies in Bibliography, Vol. 6 (1954), pp. 197-217 (21 pages). Available at: Bibliographical Society of the University of Virginia. (Accessed on December 10, 2019) .

Brooke,S. (1919) and Lewis Carroll-L.C. Dodgson (1932), and an edition of C. Rossetti in 1930.

Vita, S.(1912).West once called him a "poet of dusk".

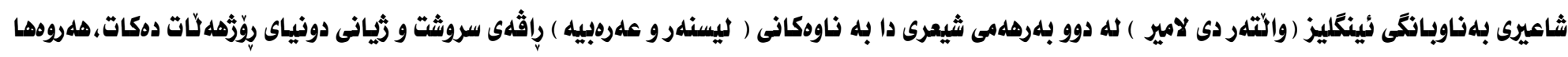

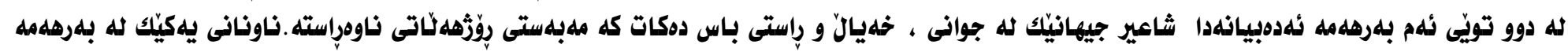

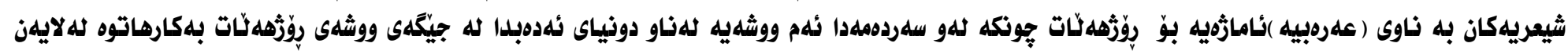

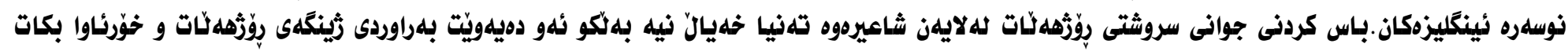

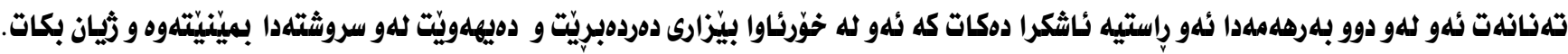

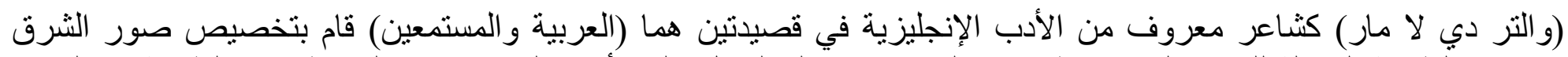

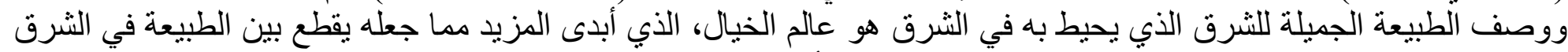

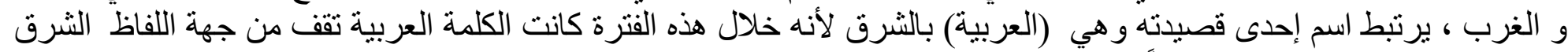

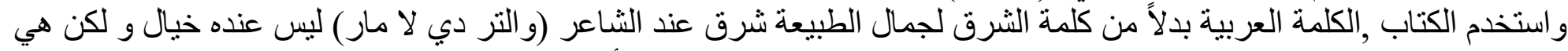

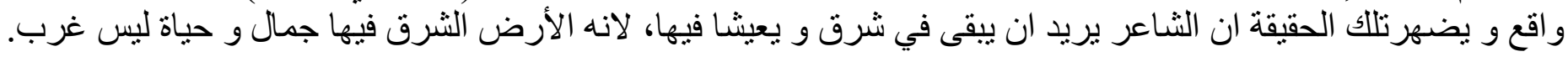

